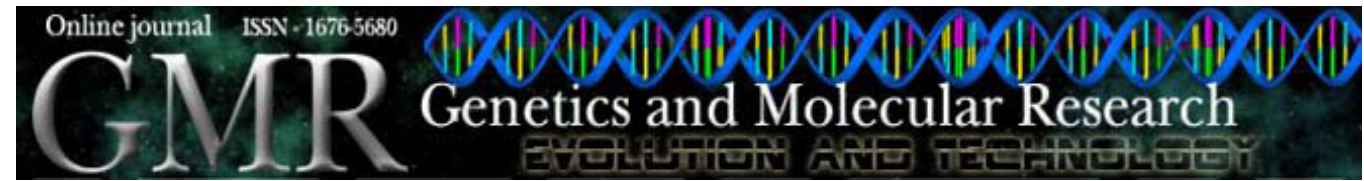

\title{
An exploratory survey of professionals on the use of stored tissue samples from minors for genetic research
}

\author{
K. Hens ${ }^{1}$, J. Snoeck ${ }^{2}$, H. Nys ${ }^{2}$, J.-J. Cassiman ${ }^{3}$ and K. Dierickx ${ }^{1}$ \\ ${ }^{1}$ Centre for Biomedical Ethics and Law, Katholieke Universiteit Leuven, \\ Leuven, Belgium \\ ${ }^{2}$ Rega Institute for Medical Research, Katholieke Universiteit Leuven, \\ Leuven, Belgium \\ ${ }^{3}$ Departement Menselijke Erfelijkheid, Katholieke Universiteit Leuven, \\ Leuven, Belgium \\ Corresponding author: K. Hens \\ E-mail: Kristien.Hens@med.kuleuven.be
}

Genet. Mol. Res. 9 (2): 973-980 (2010)

Received February 8, 2010

Accepted March 15, 2010

Published May 25, 2010

DOI 10.4238/vol9-2gmr781

\begin{abstract}
The ethical aspects of the use of stored tissue samples collected from minors are of topical interest. However, the views of professionals working in the field of genetics have not been investigated in depth anywhere. We conducted a survey among 194 such professionals in Belgium. This list was composed of the members of the High Council for Anthropogenetics, supplemented with all professionals working in the field of genetics that we found on the websites of the eight Belgian centers of human genetics and of the associated university registries. We achieved a response rate of $35.5 \%$. The vast majority $(92 \%)$ think that research on stored tissue samples is useful. Most respondents stated that parental consent is valid (82.5\%), and $76.5 \%$ thought that children should also be given the right to assent when they are able to comprehend the implications of the storage of biological samples and of genetic research. Slightly more than half put the age at which young people can understand storage or
\end{abstract}


research rather high: $16-18$ years (51 and $53.1 \%$, respectively). Although there is some consensus in the literature that donors should be allowed to give broad consent for future research on their biological samples, only $47.6 \%$ in our survey thought that parents should be allowed to consent to any future research on their children's samples. The aim of our study was to give some basis for future ethical reflections and policies on the subject of stored tissue samples from minors for genetic research. We concluded that a large majority of Belgian researchers and clinicians in the field of genetic research think research on stored tissue samples from minors is useful. They also think that parental consent for such research is valid, but that children should be allowed to assent as they grow older.

Key words: Survey; Ethics; Biobank; Genetic research; Consent

\section{INTRODUCTION}

The use of stored tissue samples from minors has gained some attention lately after the publication of a policy forum in Science (Gurwitz et al., 2009). In this policy forum, it is stated that population biobanks involving children and their tissue raise specific ethical issues that are not covered by the general discussion, which assumes that participants are adults that can autonomously decide on participation. A recently published literature review has confirmed this (Hens et al., 2009a). The main theme in the existing literature is consent: is parental consent sufficient or valid for storing biological samples from children in biobanks? Should children be allowed to give assent ('permission') when they have reached an age at which they can understand the implications of storage and research? What is this age? Are parents allowed to give broad consent for research on the stored tissue samples of their children?

There is already a substantial body of empirical literature on stored tissue samples in general. This literature is based on surveys querying the general population (Hoeyer et al., 2004; Kettis-Lindblad et al., 2006), patients (Pentz et al., 2006; Hull et al., 2008; Pulley et al., 2008; Goldenberg et al., 2009) or biobank participants (Hoeyer, 2003). The views of professionals on the ethical questions regarding stored tissue samples are far less investigated. Ruiz-Canela et al. (2009) did a survey of researchers in the USA and Spain on the issue of informed consent and the subjects' right to know the results of a study. With regard to stored tissue samples from minors, we found three surveys (Joseph et al., 2008; Goldenberg et al., 2009; Jackson et al., 2009), two qualitative studies investigating children's views (Williamson et al., 2004; Goodenough et al., 2004) and a focus group study (Kaufman et al., 2008). Only one study queried the viewpoints of professionals on the issue of tumor banking: Jackson et al. (2009) did a survey among pediatric oncology health professionals on the usefulness of tissue banking and the issue of consent in pediatric research on tumors.

Given the lack of publications in this specific area, we found it necessary to query the opinions of Belgian professionals who work with DNA samples, with regard to this subject. We asked about their opinion on the usefulness of research on stored tissue samples of children, the validity and scope of parental consent, the need for a child's assent and the age at which they thought children could understand storage of biological samples and research on these samples. This paper is a report of our findings. 


\section{METHODS}

To compile the list of addressees of our survey, we took the names of the members of the High Council for Anthropogenetics, an official Belgian body composed of geneticists from all different centers in Belgium with the task of coordinating the activities of the eight Belgian centers for human genetics. We supplemented this list with professionals whom we found on the websites of all the eight Belgian centers of human genetics and of the associated university registries. We took a broad approach to the selection of participants: if the website did not specify otherwise, we assumed the people enlisted were involved in or had a professional opinion on stored tissue samples for genetic research.

We created a structured questionnaire based on a review of the ethics literature on stored tissue samples (Hens et al., 2009b). The survey was reviewed by one medical doctor, one researcher in genetics and one researcher in biochemistry. These reviewers did not participate in the final survey.

A total of 194 questionnaires were sent out via e-mail starting on September 11, 2008. We sent out 8 reminders during the period of September 2008 to September 2009, including one postal questionnaire. No monetary or other incentive was offered. We received six notifications that the person had left the institution. We received eight notifications of people stating they did not work in the field of genetic research and that they thought the questionnaire was not applicable to them. A total of 64 surveys were returned completed (response rate $=35.5 \%$ ). We believe the rather low return rate can be attributed to different reasons. First, as we sent out the questionnaire to a rather broad audience, several recipients must have thought this was not applicable to them. Second, the questionnaire took 20 to 30 min to complete. We talked to some of the recipients, and they told us that their busy schedule did not allow them to complete questionnaires. Third, the low return rate for questionnaires among professionals in general is well known (Ruiz-Canela et al., 2009). As 95.3\% of our respondents claimed that their institute stores biological samples for genetic research, and as $46.9 \%$ stated that their educational background was in science and $48.4 \%$ medicine, we still think that the data we gathered is representative of the viewpoints of professionals in the field of genetic research in Belgium.

Response implied informed consent. The questionnaires were coded upon receipt and processed using SPSS 16.0. We generated frequency tables and used the Fisher exact chi-square test to calculate significant relationships between the findings. When we found significance in findings, we indicated this below.

\section{RESULTS}

We collected the following biographical data of respondents: gender, year of birth, whether they have children, in which province (including Brussels) do they live, educational background, number of years involved in genetic research and whether the institute in which they work stores human biological samples for non-therapeutic research. We had a fairly even distribution of males and females (42.9 vs 57.1\%), most of our respondents had children $(80.6 \%)$ and the majority had been involved in genetic research for over 4 years $(70.2 \%$ in all cases). The mean age of our respondents was 44 years $(\mathrm{SD}=11$; range $=24-69)$. An overview of these demographics can be found in Table 1 . 


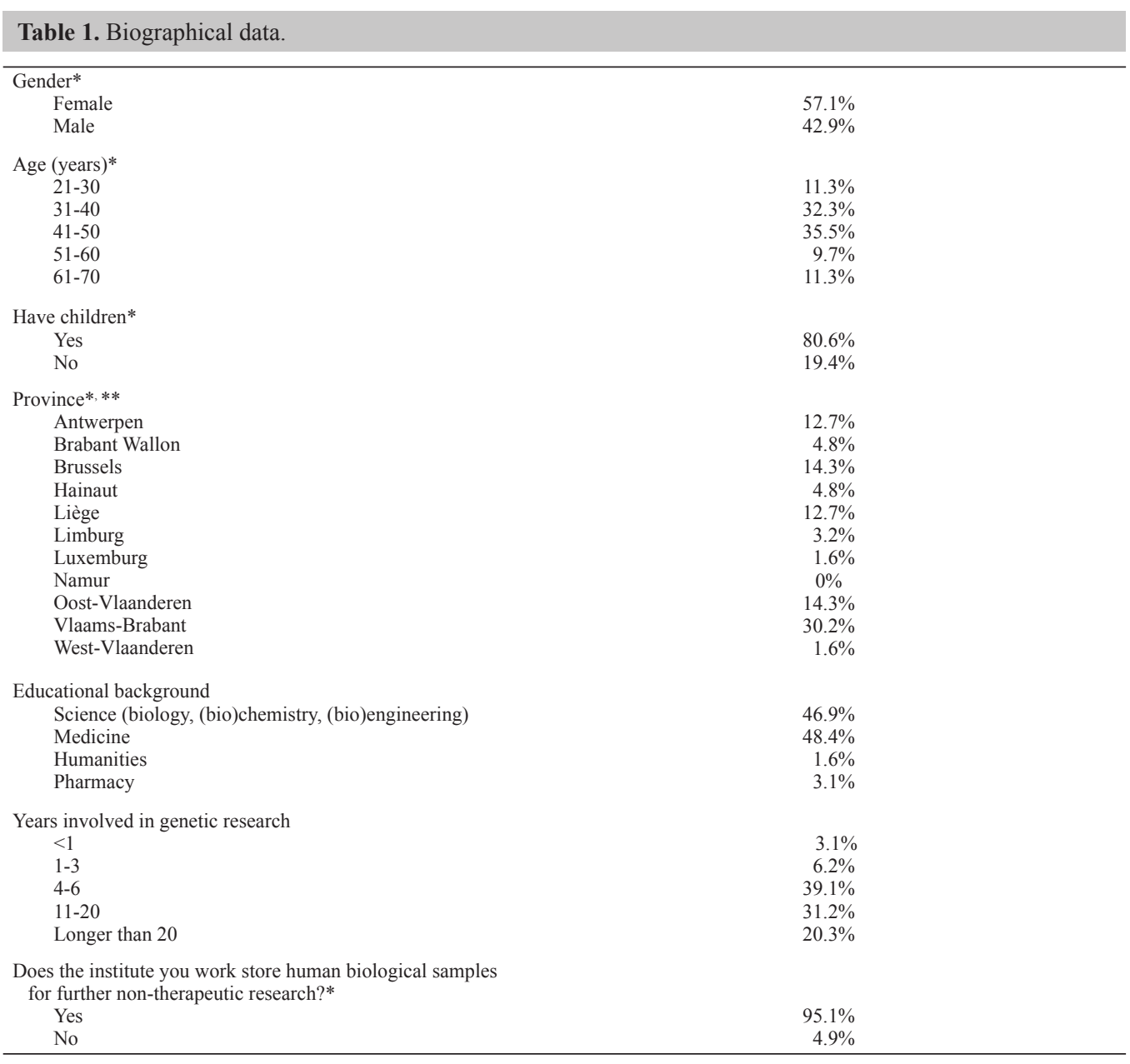

*As some respondents (maximum 3) skipped certain boxes, the valid percentages are given. **Including Brussels.

Our first set of questions was related to the usefulness of stored tissue samples from minors for research and to the need for parental consent and the assent of the child. The vast majority of respondents thought that genetic data from minors is useful for research (92\%). They also thought that parental consent is valid $(82.5 \%)$. However, the majority also believed that children should be given the opportunity to assent once they could understand the implications of storage and genetic research (76.5\%). An overwhelming majority thought that young people should be given the right to withdraw their data from a collection when they reach the age of $18(95.2 \%)$. Table 2 gives an overview of the findings for the first set of questions.

We also investigated the scope of parental consent. We asked for which types of research could parents give consent. The majority of respondents agreed that parents should be allowed to consent to either well-specified research $(79.4 \%)$ or research for a specific condition (77.8\%). A little less than half of them thought parents could consent to any possible research $(47.6 \%)$. The results are in Table 3. 


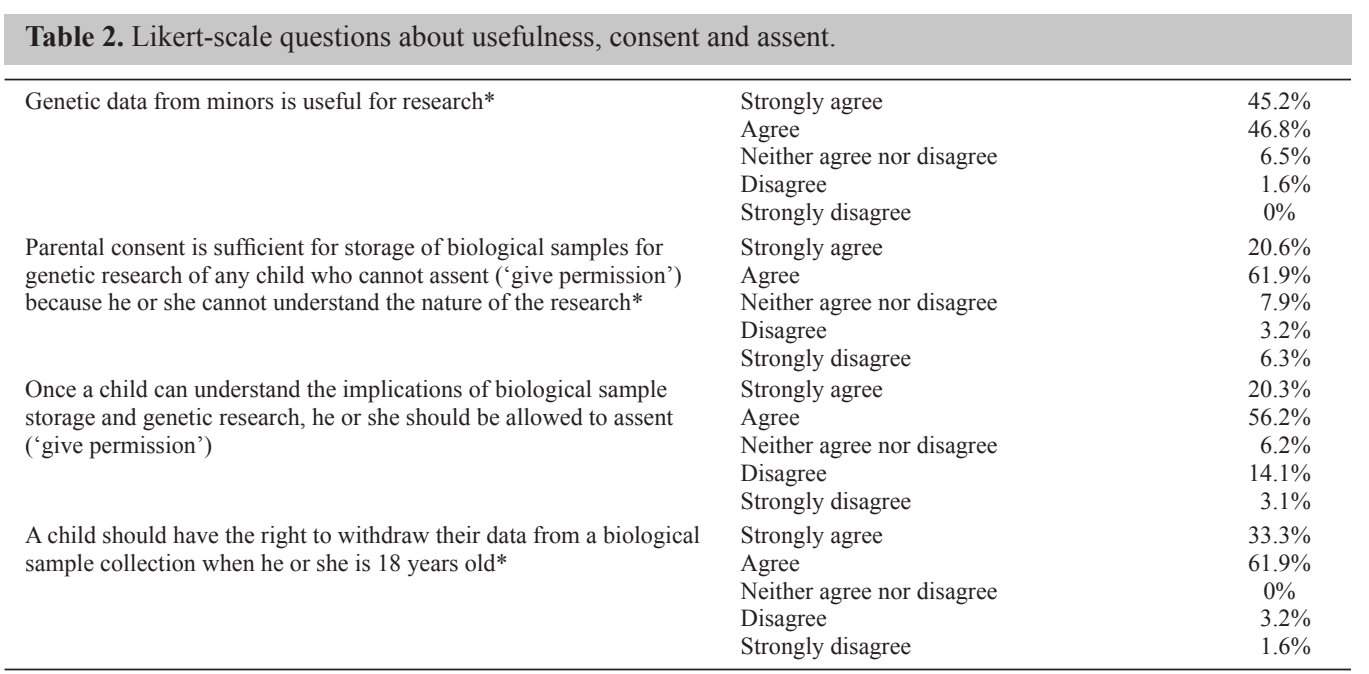

*As some respondents (maximum 3) skipped certain boxes, the valid percentages are given.

\begin{tabular}{ll} 
Table 3. To which type of research should parents be allowed to consent for their children? \\
\hline Research that is well specified at the time of consent* \\
Genetic research related to a specific gene* & $79.4 \%$ \\
Genetic research related to a specific condition* & $58.7 \%$ \\
Any possible future genetic research* & $77.8 \%$ \\
\hline
\end{tabular}

*As one respondent skipped this question, the valid percentages are given.

We also investigated at which age respondents thought children were able to understand the implications of storage of biological samples and of genetic research. A small majority thought this age was 16-18 years for both the storage of samples $(51.5 \%)$ as for the genetic research $(53.1 \%)$. We found a correlation between the age of the respondents and the answers to the question about which age people can understand the implications of storage (Fisher exact test, $\mathrm{P}=0.039$ ). The results are in Table 4 .

\section{Table 4. Age of understanding.}

\begin{tabular}{|c|c|}
\hline \multicolumn{2}{|c|}{$\begin{array}{l}\text { From which age do you think children can understand the implications of storage of biological samples } \\
\text { for future genetic research? }\end{array}$} \\
\hline $0-3$ years & $0 \%$ \\
\hline 4-6 years & $0 \%$ \\
\hline $7-9$ years & $1.6 \%$ \\
\hline $10-12$ years & $17.2 \%$ \\
\hline $13-15$ years & $29.7 \%$ \\
\hline $16-18$ years & $51.6 \%$ \\
\hline \multicolumn{2}{|c|}{ From which age do you think children can understand the implications of genetic research? } \\
\hline 0-3 years & $0 \%$ \\
\hline 4-6 years & $0 \%$ \\
\hline $7-9$ years & $0 \%$ \\
\hline $10-12$ years & $14.1 \%$ \\
\hline $13-15$ years & $32.8 \%$ \\
\hline $16-18$ years & $53.1 \%$ \\
\hline
\end{tabular}




\section{DISCUSSION}

This study demonstrates that a large majority of researchers and clinicians in the field of genetic research think that research on stored tissue samples from minors is useful. They also thought parental consent is valid, but that minors should be given the opportunity to assent once they are able to understand the implications of the storage of biological samples and of genetic research. The age when minors would be able to do so was set quite high by a small majority: around 16-18 years. Respondents also thought people should be able to withdraw their data from a biological sample collection when they turn 18 .

The need for assent from minors is consistent with the ethics literature (Holm, 2005; Helgesson, 2005; Hens et al., 2009a). It is seen as a general duty to include children in the decision making, at the moment that they can understand what is at stake. This is a right that is laid down in the United Nations Convention on the Rights of the Child (UN (United Nations), 1998) and can also be linked to the fact that in order to develop autonomy, a child should be able to exercise it (Helgesson, 2005). A small majority of our respondents suggested a fairly high age at which children can understand the implications of genetic research and the storage of their samples (16-18 years old). In a survey of clinical geneticists to decide at which age a minor can decide on having a carrier test, also this age (around 16) is given (Borry et al., 2008). There is, however, much discussion about the age at which a minor can understand genetic research. General literature regarding the capability of children to make decisions suggests that even at a very young age children can be involved in decision making (Alderson et al., 2006). However, with regard to genetic testing, others have found that even teenagers have difficulties grasping the full scope and impact of genetic information (Boddington and Gregory, 2008). Also, the legal situation in Europe on the position of minors in a health care setting is not straightforward. An overview of legal regulations shows that this position varies: the age and circumstances under which minors are allowed to make health care decisions vary in different countries, and is sometimes set as low as 14 (Portugal) (Stultiens et al., 2007). One could even question whether it is possible to establish a fixed threshold for assent or whether this is dependent on maturity and social context, and must be decided on a caseby-case basis (Wendler and Shah, 2003; Ashcroft et al., 2003). And, even if children have no thorough understanding of the implications at the moment that they are enrolled in research, do they not have the right to be informed in terminology that they can understand, even when they are below the official threshold for assent?

Our respondents almost unanimously agreed that donors should be given the opportunity to withdraw their data from a biological sample collection when they are 18 years old. This is in accordance to the ethics literature on the subject (Hens et al., 2009b). Holm (2005), for example, argues that as children have not been able to autonomously consent and give up the right to withdraw at the moment of donation, the right to withdraw for children is more important than for adults. It is less clear whether this entails a positive duty on the side of the researchers to recontact donors when they are 18 to inform them about their samples, or whether it can be left to the parents to inform their children of their participation.

A topic much discussed in the general ethics literature on stored tissue samples is the scope of consent. Should donors of biological samples be allowed to consent to any future research or should they be recontacted to give consent for each specific research? The study 
by Ruiz-Canela et al. (2009) shows that professionals prefer a less restrictive consent. Also, a systematic review by Wendler (2006) has indicated that most donors would not mind giving one-time general consent. However, our respondents were somewhat more restrictive, as they in general preferred consent for well-specified research or research on specific diseases. The difference is the fact that we asked about the right of parents to consent for their children.

Whether they have this right is not often questioned in ethics literature (Hens et al., 2009a), but the fact that this is a proxy consent possibly limits the actual scope of the consent. How to best balance on the one hand feasibility and on the other hand respect for the rights of children to make their own decisions should be determined by policy makers of pediatric biobanks before enrolling donors.

Our study has several limitations. First, there is the fairly low response rate $(35.5 \%)$, which may make our study not entirely representative of the Belgian professionals working with biological samples. Second, the section on biological samples from minors was only a part of the survey; this may or may not have influenced some of the answers; however, as we still obtained a fairly large sample of Belgian professionals in the field of genetics, and as this is a largely untrodden area, we think that our study can be the onset of a more thorough discussion.

\section{ACKNOWLEDGMENTS}

Research supported by FWO Flanders, project \#G029107. We would like to thank the reviewers of the pilot questionnaire for their valuable comments. We also thank Leen Trommelmans for her help with SPSS.

\section{REFERENCES}

Alderson P, Sutcliffe K and Curtis K (2006). Children as partners with adults in their medical care. Arch. Dis. Child 91: 300-303.

Ashcroft R, Goodenough T, Williamson E and Kent J (2003). Children's consent to research participation: social context and personal experience invalidate fixed cutoff rules. Am. J. Bioeth. 3: 16-18.

Boddington P and Gregory M (2008). Adolescent carrier testing in practice: the impact of legal rulings and problems with "gillick competence". J. Genet. Couns. 17: 509-521.

Borry P, Stultiens L, Goffin T, Nys H, et al. (2008). Minors and informed consent in carrier testing: a survey of European clinical geneticists. J. Med. Ethics 34: 370-374.

Goldenberg AJ, Hull SC, Botkin JR and Wilfond BS (2009). Pediatric biobanks: approaching informed consent for continuing research after children grow up. J. Pediatr. 155: 578-583.

Goodenough T, Williamson E, Kent J and Ashcroft R (2004). Ethical Protection in Research: Including Children in the Debate. In: Researchers and their 'Subjects' (Smyth M and Williamson E, eds.). The Policy Press, Bristol, 55-72.

Gurwitz D, Fortier I, Lunshof JE and Knoppers BM (2009). Research ethics. Children and population biobanks. Science 325: 818-819.

Helgesson G (2005). Children, longitudinal studies, and informed consent. Med. Health Care Philos. 8: 307-313.

Hens K, Nys H, Cassiman JJ and Dierickx K (2009a). Genetic research on stored tissue samples from minors: a systematic review of the ethical literature. Am. J. Med. Genet. A 149A: 2346-2358.

Hens K, Nys H, Cassiman JJ and Dierickx K (2009b). Biological sample collections from minors for genetic research: a systematic review of guidelines and position papers. Eur. J. Hum. Genet. 17: 979-990.

Hoeyer K (2003). 'Science is really needed-that's all I know': informed consent and the non-verbal practices of collecting blood for genetic research in northern Sweden. New Genet. Soc. 22: 229-244.

Hoeyer K, Olofsson BO, Mjorndal T and Lynoe N (2004). Informed consent and biobanks: a population-based study of attitudes towards tissue donation for genetic research. Scand. J. Public Health 32: 224-229.

Holm S (2005). Informed consent and the bio-banking of material from children. Genomics Soc. Policy 1: 16-26.

Hull SC, Sharp RR, Botkin JR, Brown M, et al. (2008). Patients' views on identifiability of samples and informed consent for genetic research. Am. J. Bioeth. 8: 62-70. 
Jackson C, Dixon-Woods M, Tobin M, Young B, et al. (2009). Seeking consent to tissue banking: a survey of health professionals in childhood cancer. Eur. J. Cancer Care 18: 391-400.

Joseph JW, Neidich AB, Ober C and Ross LF (2008). Empirical data about women's attitudes toward a biobank focused on pregnancy outcomes. Am. J. Med. Genet. A 146: 305-311.

Kaufman D, Geller G, LeRoy L, Murphy J, et al. (2008). Ethical implications of including children in a large biobank for genetic-epidemiologic research: a qualitative study of public opinion. Am. J. Med. Genet. C Semin. Med. Genet. 148C: $31-39$.

Kettis-Lindblad A, Ring L, Viberth E and Hansson MG (2006). Genetic research and donation of tissue samples to biobanks. What do potential sample donors in the Swedish general public think? Eur. J. Public Health 16: 433-440.

Pentz RD, Billot L and Wendler D (2006). Research on stored biological samples: views of African American and White American cancer patients. Am. J. Med. Genet. A 140: 733-739.

Pulley JM, Brace MM, Bernard GR and Masys DR (2008). Attitudes and perceptions of patients towards methods of establishing a DNA biobank. Cell Tissue Bank 9: 55-65.

Ruiz-Canela M, Valle-Mansilla JI and Sulmasy DP (2009). Researchers' preferences and attitudes on ethical aspects of genomics research: a comparative study between the USA and Spain. J. Med. Ethics 35: 251-257.

Stultiens L, Goffin T, Borry P, Dierickx K, et al. (2007). Minors and informed consent: a comparative approach. Eur. J. Health Law 14: 21-46.

UN (United Nations) (1998). United Nations Convention on the Rights of the Child. Available at [http://en.wikipedia.org/ wiki/Convention_on_the_Rights_of_the_Child]. Assessed May 18, 2010.

Wendler D (2006). One-time general consent for research on biological samples. BMJ 332: 544-547.

Wendler D and Shah S (2003). Should children decide whether they are enrolled in nonbeneficial research? Am. J. Bioeth. 3: 1-7.

Williamson E, Goodenough T, Kent J and Ashcroft R (2004). Children's Participation in Genetic Epidemiology. In: Genetic Databases: Socio-Ethical Issues in the Collection and Use of DNA (Tutton R and Corrigan O, eds.). London and New York, Routledge, 139-160. 